University of Warwick institutional repository: http://go.warwick.ac.uk/wrap This paper is made available online in accordance with publisher policies. Please scroll down to view the document itself. Please refer to the repository record for this item and our policy information available from the repository home page for further information.

To see the final version of this paper please visit the publisher's website. Access to the published version may require a subscription.

Author(s): Wyn Grant

Article Title: Pressure Politics: A Politics of Collective Consumption?

Year of publication: 2005

Link to published version: http://dx.doi.org/10.1093/pa/gsi028

Publisher statement: This is a pre-copy-editing, author-produced PDF of an article accepted for publication in Parliamentary Affairs following peer review. The definitive publisher-authenticated version [Grant, W. (2005). Pressure Politics: A Politics of Collective Consumption? Parliamentary Affairs, 58, pp. 366-379] is available online at: http://dx.doi.org/10.1093/pa/gsi028 


\section{PRESSURE GROUPS: A POLITICS OF COLLECTIVE CONSUMPTION?}

Wyn Grant*

The past year has seen a further expansion of the activities of protest groups. The incursion of hunt protesters on to the floor of the House of Commons attracted particular attention, as did other acts of civil disobedience by defenders of the right to hunt with dogs who promised to defy and legislation that was passed. A variety of stunts carried out by Fathers 4 Justice also attracted considerable media coverage. Attempts by animal rights militants to stop the activities of Huntingdon Life Sciences continued and led firms and universities to resort to novel legal remedies. There is some evidence that Britain is becoming a more ‘uncivil society’ as far as pressure group activities are concerned.

In Pressure Groups and British Politics (2000) I argued that there has been an important shift in British pressure group politics from a politics of production to a politics of collective consumption. ${ }^{1}$ The politics of production is centred on a struggle between management and labour over the distribution of the fruits of the production process, a struggle in which government becomes involved as a mediator, subsidiser and regulator. In its most developed form, tripartism or neo-corporatism, it can have a transformative effect on the relations between government and leading economic pressure groups. The politics of collective consumption is concerned with the outcomes of the production process rather than what happens in the production process itself. It is concerned with the externalities of that production process. It is called a politics of collective consumption because at its core is a concern with collective goods, or at least goods which have some of the characteristics of public goods. 
The boundaries and characteristics of this form of politics are less clear than those of the politics of production. In part, this is because the shift the character of pressure group politics reflects changes in society itself. As society becomes more fragmented and moves away from a situation in which people's roles were more commonly defined for them, often in class terms, citizens can select and construct identities for themselves. This then becomes reflected in the way that pressure politics is expressed and organised. It involves a move away from policy communities centred around compartmentalised government departments or dominated by established professions. It is more compatible with new patterns of networked governance that blur the traditional distinctions between state, market and civil society. The politics of production took those distinctions as givens, but attempted to bridge them through intermediary institutions or arrangements. It must be emphasised, however, that the politics of production has not disappeared. Roles such as 'employer’, ‘farmer', 'doctor' and 'worker' still convey meanings that can provide a basis for political action that proceeds from the identification of shared interests.

The choice of the term 'collective' consumption was deliberate in order to make a distinction between individualised, private forms of consumption and those that had a link between an individual choice, broader social values and some notion of a public good. The question then arises of how we can distinguish those forms of political action that are in some sense collective, not so much in the form of the action itself, but in terms of the pursuit of a broader public interest. Thus, a consumer who purchases a 'fair trade' product in a supermarket is making an individual choice in isolation from others, but is doing so with some broader social goals in mind. In a sense it is analogous to the 
debate about whether the act of voting is degraded if it no longer takes place in a public setting (if voters can vote by post rather than going to a polling station). In an increasingly individualised and fragmented society, it is no longer going to be possible to distinguish collective acts simply by the fact that they take place in the presence of others: joining a political campaign on the internet would be another example. What is important is the balance between the action being other-regarding or devoted to particular and private interests.

This distinction is not, however, easy to apply in practice. NIMBY (not in my back yard) protesters, who oppose new developments, airports, electricity pylons or telephone masts often seem to be preoccupied with the value of their properties or, at best, concerns about the health of their families. They are open to criticism on a number of fronts. They can be accused of hypocrisy: they oppose the location of a phone mast near their houses but use mobile phones themselves; or they oppose the opening of a new airport but fly frequently by plane themselves. They are also open to the charge of protecting the interests of the better-off section of the population. In the debate over the opening of Coventry Airport to cheap flights, it was said that those complaining lived in villages with expensive housing whereas those using the flights looked like typical shoppers in Asda who would not otherwise be able to afford to fly away on holiday.

Nevertheless, there is a counter argument that NIMBY protesters represent the last line of defence against ill conceived or damaging development projects, and that if they did not protest against them, many of the projects would go ahead without challenge. However, these broader social benefits arise almost as an accidental by-product of the main objectives of the protesters. NIMBY protesters often deploy broader 
environmental or health arguments, but this should not conceal their main purpose which is to protect their own particular interests. They rarely argue, for example, that air traffic in general should be restrained, only that planes should not fly over their house. They do not usually offer constructive alternatives: the phone mast should be removed, but they rarely suggest where it might go. The political action is collective in the sense that it refers to a particular set of negative externalities, whether real or imagined, but the solutions offered are not. If anything, such protests are tending to proliferate, in part reflecting the broader pressures that exist in a prosperous and densely populated country like Britain. They are also increasingly resorting to direct action tactics such as demolishing phone masts. They thus contribute to a problem of governability that is associated with the politics of collective consumption. It is a politics that is less amenable to the elite bargaining and mediation that characterised the politics of production. This reflects the fact that the actors involved are 'sporadic interventionists' who lack an established relationship with political decision-makers and an understanding of the normal routines of the political process. It is also because there is often little room for compromise: either the phone mast is removed or it stays.

Are environmental issues increasingly being pursued in terms of particular, local and narrowly defined problems rather than some broader conception of priorities for the ecosystem as a whole? The then chief executive of the Campaign to Protect Rural England (CPRE), Kate Parminter, suggested in a February 2004 speech that the real benefits in terms of membership of the public interest in conservation were being derived by organisations that offered selective incentives such as the National Trust and the Royal Society for the Protection of Birds (RSPB). In a time-poor society, there was less 
interest in organisations like Friends of the Earth or the CPRE that encouraged active participation in civil society. It is, of course, the case that sometimes the broadly based environmental groups undermine their case by appearing to exaggerate. Greenpeace had to admit an error of fact in its campaign about the Brent Spar oil platform in 1995 and the dispute over the so-called 'ghost ships' from the United States to be broken up in Hartlepool in 2003 led to accusations that Friends of the Earth had exaggerated the scale of the problem. More generally, whilst it is possible to encourage people to contribute to recycling campaigns that demand relatively little of them while giving them the satisfaction that they have 'done their bit' for the environment, they are less likely to accept lifestyle changes of the kind that would be required to tackle global warming. Even problems that are more specific are difficult to tackle. Airports and aircraft are a major source of congestion and pollution, but cheap flights are such an important element of the lifestyles of so many people that any increase in their prices as a result of environmental taxes would be politically unpopular.

Although many environmental groups are well resourced, it is easy to become mesmerised by the fact that the RSPB has more members than all Britain's political parties combined and to overlook the more general imbalances between producer and citizen groups. The Food Standards Agency has made a systematic effort since its establishment to consult with 'stakeholders'. However, the stakeholders responsible for enforcement of food standards legislation had difficulty in maintaining attendances at a meeting organised for local authorities. The meeting for producers held in the summer of 2004 attracted 24 organisations ranging from the National Farmers Union to the Snack, Nut and Crisp Manufacturers Association. The corresponding forum for consumers was 
attended by only twelve organisations. The terrain of new forms of politics is still less firmly established than that of the politics of production.

Setting the political agenda: the case of obeisty

An interesting contribution to the study of pressure groups suggested that the influence of outsider groups may have been underestimated as their main contribution may have been in relation to agenda setting rather than influencing the policy process itself. ${ }^{2}$ The politics of collective consumption is in large part about opening up new spaces on the political agenda, introducing issues that are embarrassing for producer interests and difficult for them to counteract. Nevertheless, outsider tactics may be counterproductive, while interventions by authoritative experts engaging in a dialogue with decision makers can still be highly effective. These ideas are explored here in relations to two issues that have attracted attention in the past year: obesity and diet, and more specifically the issue of high salt levels in processed foods; and the issue of how fathers of children are treated in terms of contact with their children after divorce settlements.

Obesity attracted considerable media attention in 2004. The present phase of interest in the subject followed investigations conducted by the World Health Organisation. However, reports of an international organisation would not attract such extensive interest unless they pushed a number of political buttons. Obesity is on the increase in western societies, and it is a visible problem that can be easily documented and dramatised by the media. Indeed, some accounts seem to draw on anti-American narratives. The broader significance of the issue lies in its links with health policy. The increased risks of illness and mortality attracts the interest of government because it 
wishes to promote a healthier population, not least because of the ever increasing costs of public health care.

High levels of salt in processed food form part of this debate and one that attracted particular attention in Britain in 2004. Essentially, manufacturers use salt in many processed food products, including bread, to make them more palatable to consumers. It is very difficult even for well-informed consumers to avoid products containing high levels of salt. Research suggests a clear link between salt levels in food and high blood pressure, increasing the risk of heart disease and stroke. The food industry has tried to answer these criticisms by claiming that there is not such thing as an unhealthy food, only an unhealthy diet. It has been suggested that the food industry is where the tobacco industry was some forty years ago, when the link between cigarette smoking and cancer was firmly established. The parallel is not exact because people can survive without tobacco but are unlikely to be able to do without processed food. However, it is interesting that one response of the food industry has been to introduce 'light', e.g. low salt, versions of its top brands. Light cigarettes are now discredited and the food industry could find itself faced with similar legal difficulties as tobacco if it makes claims that are unsustainable.

The food industry shows signs of losing the debate over salt levels in particular, despite a public relations campaign over the last decade by the Salt Manufacturers’ Association and other parts of the industry to persuade health professionals and the general population that the evidence about salt is not clear and that action is therefore not justified. One of the reasons for this lack of success is the knowledge-based campaigning of organisations such as Consensus Action on Salt and Health (CASH). CASH is 
chaired by a consultant in cardiovascular medicine at St. George’s Hospital in London and bases its arguments on scientific and medical evidence. It was set up in 1996 in response to the refusal of the Chief Medical Officer to endorse the recommendations of an official advisory committee to reduce salt intake, a decision that happened to coincide with the withdrawal of funds to the Conservative Party by the food industry. Drawing on the wealth of scientific evidence that links high salt intake to health problems, CASH has set itself the realistic objective of reaching a consensus with food manufacturers and suppliers that salt does have adverse health effects and persuading to gradually reduce the levels of salt in processed foods. Some success has been achieved, with a reduction of $5 \%$ in the level of salt in bread announced in July 2004, though CASH argued that this was insufficient to have a beneficial effect.

There is a very strong producers lobby on these issues, with the National Farmers Union (NFU), the British Retail Consortium, the British Hospitality Association and the Food and Drink Federation taking a leading role. The issue is also a difficult one for government to handle and it has been possible for the industry to use the classic tactic of exploiting divisions within government. A number of policy options have been explored within government. However, their selection is influenced by New Labour's preference for a good working relationship with business, leading it to choose voluntary regulation wherever possible. This is reinforced by concerns that the Government could be accused of creating a 'nanny state' if it intervened too much in what people eat. Taxing unhealthy foods and banning food advertising targeted at children are options favoured by the National Consumer Council. It would be possible to apply differential VAT treatment to foods, but such an approach was rejected by the Chancellor. Banning 
advertising and regulating the advertising industry were seen as too interventionist by Downing Street. In any case problems with defining advertising aimed at children could make a ban unworkable. Tessa Jowell, the Secretary of State for Culture, Media and Sport, responsible for the advertising industry, was not convinced that banning advertising would bring about a big change in children's eating habits and believed that the answer was to be found in getting children to exercise more. The coalition of opponents widened when ITV complained that a ban would damage its ability to produce original programmes for children. It seemed likely that some kind of voluntary ban would be negotiated with the advertising industry, combined with clearer labelling of food products to enable consumers to make informed choices, although perhaps not going as far as the 'red, amber, green’ traffic light system advocated by consumer organisations. In exchange for avoiding punitive laws on advertising and labelling, firms would be encouraged to make donations and provide sponsorship as an 'anti-obesity levy' to be used to fund new sports centres.

The clear divisions on this issue between different government departments offered openings for industry lobbyists. In June 2004 the Public Health minister, Melanie Johnson, leaked a document that 'named and shamed' 27 food companies for refusing to make substantial cuts in the salt content of their food. The Department of Health's view was that it was necessary to keep up pressure on the industry in order to achieve a satisfactory voluntary agreement. However, other government departments thought that the Health Department's approach had damaged the delicate and long-term process of persuading the food industry to change its behaviour. The food industry argued that the episode had damaging confidence in the process, although it chose to characterise what 
had happened as bungled news handling rather than an aggressive act by government. The fact that departments were briefing against each other exposed the divisions in government, allowing the industry to seize the initiative and present itself as an advocate of constructive dialogue that had been mistreated. The final policy solution has yet to emerge, but it is likely to stop a long way short of comprehensive compulsion. Health and consumer groups have been successful in attracting media attention to the issue, placing it on the political agenda and counteracting arguments that there is not a problem. Faced by a well-resourced producer lobby, they have been far less successful in winning support for the policy solutions they favour and outcomes in terms of the salt intake that arises from processed food have changed very little so far.

Fathers 4 Justice is an organisation founded in December 2002 that has won widespread media attention through its dramatic stunts. These have often involved activists dressed in costumes such as Spider-Man, Batman or Santa Claus climbing high or prominent buildings and gantries where they can be seen by large numbers of people and unfurling banners. In November 2002, one activist wearing a Spider-Man outfit perched on a giant crane near Tower Bridge, leading to street closures that disrupted traffic in the City of London for several days. Fathers 4 Justice has always claimed that it uses humour to advance its cause, although officials working for the Child and Family Court Advisory Services (Cafcass), who had their front doors painted purple, might not share the joke. When members released condoms containing purple powder during Prime Minister's Question Time, leading the chamber to be evacuated and prompting a major security alert, it was suggested that the group had stepped over the fine line between spreading its message and alienating the public. When a supporter dressed in a 
Spider-Man outfit scaled a balcony at Buckingham Palace in September 2004 the subsequent media discussion was largely in terms of the security flaws that had been exposed. This was also the case when hunting protesters invaded the floor of the House of Commons.

Fathers 4 Justice want to change the terms and language of family law to reassert the rights of rights of UK fathers to see their children after divorce. They are not complaining about the wording of the 1989 Children's Act, but the way in which it has been interpreted by the courts. They argue that the Lord Chancellor's department has failed to uphold the will of Parliament, particularly in terms of the operations of Cafcass which is the department's responsibility. Fathers 4 Justice appeals to a substantial constituency of disgruntled fathers with some ten thousand members. Its tactics are very much those of an outsider group. It claims to have a 'twin-track strategy based around publicity and press. ${ }^{3}$ Apart from its stunts, it is now planning to put up candidates at the next general election in the hope that it can influence the fortunes of Labour Party candidates. It faces a key dilemma of outsider groups, the challenge of more militant splinter groups emerging with a number of hoax bomb warnings sent to Cafcass in the autumn of 2003. Actions like these could further damage the group's reputation. Its stunts have already led to comments that they demonstrate why women do not feel that they always want men to have access to their children. Nevertheless, it claims that 'We are now on the political agenda, so we have achieved one of our key objectives. ${ }^{4}$ However, having placed the issue on the political agenda, it has had no real success in changing the decisions of the courts or the conduct of Cafcass. In a media dominated age, there is a risk that organisations may consider that getting their issue on the political 
agenda is enough whereas as in fact it is only the start of the battle. Apart from the fact that the political agenda is crowded and issues may easily get pushed off again, Fathers 4 Justice faces the problem that it is particularly concerned about the way in which legislation has been implemented through the courts, advised by Cafcass. This is perhaps a more difficult target than changing or repealing a particular piece of legislation as a number of judicial decisions could be involved, although Fathers 4 Justice is particularly annoyed by a ruling by Lord Justice Thorpe that they see as unfairly favouring mothers. More generally, organisations have to be able to develop feasible and politically attractive solutions to current policies. A rival group, Parents for Equality, is pursuing an insider strategy that does not rely on protest actions but is instead based on education and persuasion directed at decision-makers. It will be interesting to see whether they make a greater impact on policy, although it could be argued that the door has been opened for them by the tactics of Fathers 4 Justice.

\section{Animal Rights Militants}

The activities of animal rights militants continued to be a focus of attention over the past year. Government ministers and others characterised their activities as a form of terrorism, and they are certainly far removed from traditional pressure group activities. They have, however, been very effective, particularly in the use of 'tertiary' tactics in which firms are targeted who supply services to firms who deal directly with the alleged violator of animal rights . Although it has been suggested that only somewhere between twenty and fifty people are involved in the most militant activities, efforts to arrest and convict them have met with patchy success at best. 
Although activities directed at Huntingdon Plant Sciences have continued, and there has been a new protest directed at premises producing guinea pigs for medical experiments in Staffordshire, the focus of attention has shifted to an animal laboratory Oxford University planned to build. This proposed building has been portrayed as where a line in the sand will be drawn against animal rights militants, allowing government to win a victory of the kind it secured over the construction of the Newbury by-pass in the 1990s which subsequently diminished the extent and effectiveness of protests against new road projects. The Oxford project has been seen as particularly important after Cambridge University abandoned plans for a primate research centre where neurological experiments would have been carried out on monkeys. The university said that it could not proceed because of rising costs, including measures to protect the facility from militant campaigners. The Oxford project suffered a serious setback when a construction company, Montpellier Group, pulled out of a £18m contract to build the laboratory after a letter warned its investors of activity by the animal rights movement. The letter prompted a $20 \%$ fall in the company's share price. The Construction Confederation warned that its member companies would refuse to work on controversial animal research projects unless their clients were prepared to indemnify them against the financial consequences of attacks by animal rights extremists, an almost impossible request to meet. Government assurances that the army would be deployed if necessary to secure construction of the facility were of little value if no builders could be found to undertake the work, unless troops were used for the construction work itself on the model that had to be adopted after attacks on builders in Northern Ireland. 
The government did amend its Anti-Social Behaviour Act in January 2004, creating an offence of aggravated trespass to cover business premises, and convictions have subsequently been secured. The courts have also taken a generous view of restrictions that can be secured by companies under anti-harassment laws. For example, the BOC group was granted a temporary injunction in April 2004 protecting around 10,000 employees in exclusion zones around corporate property and employees' homes. In January 2004 wide-ranging injunctions were granted to protect 500 employees of Emerson Developments, a property company providing the headquarters for Yamanouchi, a Japanese group that is a significant customer of Huntingdon Life Sciences. Oxford University also sought an injunction to provide exclusion zones around all its buildings, the homes of named persons and the premises of contractors. It also sought to limit demonstrations to one a week by no more than twenty-five protesters for four hours during the day at a designated site. If this injunction is granted in the form sought, it could have wider implications for legitimate forms of peaceful protest.

The government has, however, been criticised by the pharmaceutical industry for not making more use of existing legislation and for not introducing further legislation. The Association of British Pharmaceutical Industries claims that in the first three months of 2004, 32 company directors received threatening visits at home from activists, compared with ten in the preceding year, and instances of damage to property doubled. It has been suggested that anti-terrorism legislation should be used, while there have also been calls from the industry for specific legislation to make it a criminal offence to intimidate people working in life sciences, similar to the laws introduced to control football hooligans. The government has, however, refused to introduce legislation specifically 
directed at animal rights activists, claiming that it would take too long to implement. Indeed, it is difficult to see how a law that specific could be properly drafted. There are also divisions within the government on the issue, reflecting broader concerns within the Labour Party about animal testing. The government is, however, under continuing pressure to take more effective action. In a private meeting with the Prime Minister in May, the heads of two of the world's largest pharmaceutical companies, GlaxoSmithKline and AstraZeneca, threatened to withdraw new research and development investment from Britain unless action was taken against animal rights militants. Apart from such economic consequences, if the tactics used by the animal rights militants continue to be seen to be effective, they could be copied by other groups, increasing the strains on the political process as a whole.

\section{Producer Groups}

In September 2004 Trade and Industry minister Gerry Sutcliffe criticised both the Confederation of British Industry (CBI) and the Trades Union Congress (TUC). The fact that such an attack could be made emphasises the extent to which pressure group politics has changed since the 1970s, when government often seemed to subordinate to the major economic pressure groups in its attempts to establish a tripartite partnership relationship with them. Sutcliffe warned both organisations that they needed to 'raise their game' to avoid losing their relevance. Critical remarks about government policy by Brendan Barber, the TUC General Secretary, before its annual conference were characterised as 'slightly defeatist', leaving Sutcliffe 'a bit disappointed'. ${ }^{5}$ As far as the TUC is concerned, part of the context is that the organisation has been under threat from the four biggest member unions. There have been complaints that the TUC's 
moderation has come close to toothlessness; but the more fundamental issue is what role there is for the TUC as a coordinating secretariat when the government, and particularly the Prime Minister, want to distance themselves from the unions. The government has, however, proposed a $£ 10$ million fund for union modernisation to help the unions to improve their operations, a proposal that drew a furious reaction from business. The fund is intended in part to help unions to recruit members in areas of the economy which do not have a strong union presence, such as information technology and the service sector. The government's view is that unions should have access to state help in the same way that business gets assistance through grants and business advice centres.

Sutcliffe also criticised the CBI, complaining about what he called 'Digby's rants', the periodic attacks on the unions by Digby Jones, the CBI's Director-General. He has also criticised the government from time to time. These criticisms partly reflect his own background in the organisation's Midlands region. Compared to his predecessors as Director-General, who often came from management consultancy, he has perhaps been more attuned to the CBI's membership base and less concerned about offending the government. Despite the government's reputation with its own Labour supporters for being unduly sympathetic to business interests, its standing in the business community is ambivalent. A survey by the CBI found that $39 \%$ of the executives questioned thought that government was unfriendly to business, against $31 \%$ who thought it was friendly and a considerable proportion who could not give a clear opinion. However, $75 \%$ said that they thought the government was either slightly, or much less business friendly than five years ago. ${ }^{6}$ A constant complaint from business is about the incursions of the 'regulatory state', although it is often unclear whether the main complaint is about the 
transaction costs ('red tape') of implementing government regulation or about enhanced worker rights in fields such as parental leave. Given that much of the regulatory burden emanates from the European Union, attitudes of business towards the EU are less favourable which may have implications for the conduct of the referendum on the EU constitution.

There is a risk that the CBI may find itself eclipsed by more direct relations between firms and government, particularly given the Prime Minister's preference for dealing with company executives who are seen as 'movers and shakers'. Ministers and their advisers have tended to see business associations as 'consensus-seeking, slow-moving bodies, a good deal less exciting than the companies which they represent, and less likely to display can do vigour than the chief executives of two or three leading companies from a sector. ${ }^{7}$ This perception has led to an enhanced role for the shadowy Multinational Chairmen's Group, which enjoys an annual meeting with the Prime Minister. In practice, however, many of government's relations with business are still conducted through the trade associations that represent particular sectors of the economy. The Department of Trade and Industry (DTI) takes the view that only a handful of trade associations are really effective and that they form part of the problem rather than part of the solution as far as government-business relations are concerned. This view is confirmed by a survey of two thousand businesses conducted by Citigate Dewe Rogerson which found that $40 \%$ of those questioned thought that trade associations acted more like 'old boys' clubs' than effective lobbying organisations. ${ }^{8}$

However, the Labour government has been less interested in reforming trade associations than its Conservative predecessor, even though it has continued to provide 
financial support for the benchmarking activities of the Trade Association Forum. As Macdonald notes, 'The 1997 Labour government has displayed a more neutral attitude towards trade associations. Ministers have said that they hoped that companies and trade associations would realise that better representation from fewer Associations would be in the interests of business. But they have not seen it as part of a Labour Government's role to stimulate reform. ${ }^{9}$ To some extent, the inadequacies of trade associations have been compensated by the existence of sponsorship divisions within the DTI that serve as representatives within government for particular sectors of the economy. These still exist, but are not as well resourced as they once were. However, the future of the DTI is under threat. The Liberal Democrats have a policy of abolition. As part of Labour's attempt to cut civil service numbers, it is likely that DTI staff would be considerably reduced if the policy is fully implemented which would inevitably lead to a further downgrading, if not disappearance, of the sponsorship function. Any substantial erosion of the role of the DTI would have profound implications for business-government relations.

The emergence of Farmers for Action, a radical group that uses direct action techniques based on a French model, has been a thorn in the side of the well established insider group, the NFU. The traditional response of the NFU to such breakaway groups has been to ignore them and hope that they will go away. However, Farmers for Action has established itself as a permanent fixture in the political landscape of farming. The NFU has therefore moderated its response to it and, in conjunction with four other farming organisations, entered into a 'loose alliance' with them in the summer of 2004 to work together to support dairy farming, the main area of concern of Farmers for Action. 
They have not backed away from direct action techniques, although the frequency of demonstrations does appear to have dropped and the some farmers have criticised it for developing too close a relationship with dairies and the large retail groups. Outsider groups are always vulnerable to criticism from some of their own members if their militancy appears to decline.

The broader significance of this development is that it represents a coalition, albeit a very loose one, between an established insider group and an insurgent outsider group. It is possible that such informal groupings will become more common as a response by insider groups to the enhanced success of outsider tactics. However, the NFU is still very successful at changing the details of government proposals in a way that considerably benefits farmers. A Department of Environment, Food and Rural Affairs consultation paper on the implementation of cross-compliance measures designed to protect the environment suggested that a two metre uncultivated strip in fields should be measured from the edge of the hedge or ditch. The NFU managed to get this changed to the centre of the hedge or ditch will cut the amount of land that needs to be taken out of production to the considerable benefit of farmers. This suggests that traditional lobbying techniques by well-established groups can still be very effective.

\section{Conclusions}

Nevertheless, the resort to militant or disruptive tactics appears to be increasing. The politics of collective consumption, a trend that appears on the surface to offer a more disinterested pursuit of the public interest, is often concerned in practice with the defence of property rights or the availability of selective incentives. These tendencies could be related to a more general decline of trust in politicians and a greater cynicism about the 
political process. However, they may also reflect unrealistic expectations among citizens about what the political process can deliver. It is, of course, easy to become too sentimental about old forms of 'club government' in which a select group of insider groups engaged in a private dialogue with government that lacked transparency and allowed a secretive exercise of influence for private ends. Big business influence on government has far from disappeared and, if anything, it is stronger than ever. Perhaps what is needed is more of an effort to ensure that groups are internally democratic and representative of the interests or causes for which they claim to speak. As other intermediary institutions have been eroded, freely formed associations are one indicator of a healthy civil society. The dialogue they engage in with government has to recognise the diversity of opinion in an increasingly fragmented society and the fact that not all demands can be satisfied.

\footnotetext{
${ }^{1}$ Wyn Grant, Pressure Groups and British Politics, Palgrave-Macmillan, 2000, Chapter 9

2 David Toke and David Marsh, 'Policy Networks and the GM Crops Issue'. Public Administration, 2003.

${ }^{3}$ http://www.fathers-4-justice.org/introducing.html, visited 26 August 2004

4 http://www.reuters.co.uk/news visited 26 August 2004

5 Financial Times, 10 September 2004.

${ }^{6}$ Financial Times, 24/25 January 2004.

${ }^{7}$ A Macdonald, The Business of Representation: the Modern Trade Association, Department of Trade and Industry and Trade Association Forum 2000, p.7

${ }^{8}$ Financial Times, 19 April 2004.

${ }^{9}$ Macdonald, The Business of Representation, p.7.
} 